\title{
Kuşaklararası Tüketim İlişkilerine Sosyoekonomik Bir Bakış ${ }^{1}$
}

\author{
DOI: 10.26466/opus.765680
}

\author{
Mehmet Cenker Tuncer* -Nurgün Oktik** \\ *Arş. Gör., Maltepe Üniversitesi \\ E-Posta: mehmetcenkertuncer@maltepe.edu.tr \\ ORCID: $\quad$ 0000-0002-9513-150X \\ **Prof. Dr., MaltepeÜniveristesi \\ E-Posta: nurgunoktik@maltepe.edu.tr \\ ORCID: $\quad$ 0000-0003-4910-9464
}

\begin{abstract}
Öz
Bu çalışma İstanbul ilinde ikamet eden Bebek Patlaması, X ve Y kuşaklarına mensup bireyler ile gerçekleştirilmiştir. Araştırmanın konusu kuşaklararası tüketim ilişkilerinin incelenmesidir. Araştırma kapsamında 180 kişisye anket uygulanmıştır. Elde edilen veriler SPSS 25.0 programı kullanılarak analiz edilmiştir. Bebek Patlaması Kuşağı her şeyden önce, eğitimde göstermiş oldukları atılım açısından oldukça dikkat çekicidir. Bununla birlikte, Bebek Patlaması Kuşă̆ı diğer nesiller arasında en çok "yiyecek ve içecek", "giyim" ve "yardım" a harcama yapan nesildir. X kuşağı, kredi kartı sahipliğinde diğer nesiller arasında ilk sırada yer almaktadır. Aynı zamanda X Kuşağı, Bebek Patlaması Kuşağında çevrimiçi platformlara üyelik, çevrimiçi gazete okuma alışkanlıkları ve lüks tüketim alışkanlıkları gibi nispeten düşük olan yeni tüketim kalıplarına yönelmiştir. $Y$ kuşă̆ı, diğer nesiller arasında harcamalarında eğlencenin en büyük payını paylaşan nesildir. Kredi kartı sahipliği ve çevrimiçi platformlarda zaman harcamak gibi bulgular X Kuşağı ile benzer olsa da çevrimiçi platformlardan alı̧̧veriş konusunda X Kuşă̆ı'n geride bırakmışlardır. Araştırmanın bulgularına göre kuşakların Türkiye'nin özel tarihinden etkilenmekle beraber evrensel bir anlatının da bir parçası olduğu gözlemlenmiştir.
\end{abstract}

AnahtarKelimeler: Tüketim, Kuşaklar, Tüketim İlişkileri, Üretim İlişkileri, Kuşaklararası Aktarım

Bu makale, Mehmet Cenker Tuncer'in Maltepe Üniversitesi Sosyal Bilimler Enstitüsü Sosyoloji Anabilim Dalı'nda Prof. Dr. Nurgün OKTiK danışmanlığında hazırladığı "Kuşaklar Arası Değişen Tüketim Iilişkileri Üzerine Sosyoekonomik Bir Inceleme" başlıkı (2019) yayımlanmamış yüksek lisans tezinin bir kısmındaki niceliksel araştırma üzerinden üretilmiştir. 


\title{
A Socioeconomic Investigation On Changing Consumption Relations Between Generations
}

\begin{abstract}
This study was conducted within dividuals belonging to the Baby Boomer, $X$ and $Y$ generation sresiding in Istanbul. The subject of the research is the examination of inter generational consumption relations. Within the scope of theresearch, 180 people weresurveyed. The data obtained were analyzedusing SPSS 25.0 program. The Baby Boomer Generation is first and foremost remarkable in terms of their breakthrough in education. Withal, the Baby Boomer generation is the generation that spends the most on "food and beverage", "apparel" and "aid". Generation X ranks first among other generations in credit card ownership. Generation X has turned towards new consumption patterns that are relatively low in the Baby Boomer generation, such as membership in online platforms, online newspaper reading and luxury consumption habits. Generation $Y$ is the generation that allocates the most share of entertainment in its spending among other generations Although the findings such as credit card ownership and spending time on online platforms are the same as the X Generation, they have passed the X Generation far behind in shopping from online platforms. Accordingtothefindings, it has beenobserved that, althoughaffectedby Turkey'sspecificconditions, generationsarepart of a universalnarrative of history.
\end{abstract}

Keywords: Consumption, Generations, Relations of Consumpiton, Relations of Production, Intergenerational Transfer 


\section{Giriş}

Tarihsel süreçlerde değişimi anlayabilmek, değerlendirmek ve ait oldukları tarihsel dönemi betimleyebilmek adına farklı kavramsallaştırmalar bulunmaktadır. Kuşak kavramı bunlardan birisidir. Comte, kuşakların insanlığın ortak bilgisinin aktarıcısı olduğunu iddia eder. Kuşaklar aracılığı ile tarih ve tarihin içerisinde yaşanmış her türlü olay bir sonraki nesle aktarılır. Dolayısıyla bilginin aktarıcısı olarak kuşaklar toplumun devamlılığı ve yenilenmesi açısından oldukça önemli bir yere sahiptir.

Mannheim (1952), kuşak bilinci üzerinden oluşturduğu kuşak teorisinde bireylerin sadece aynı tarih aralığı içerisinde doğmuş olmalarının onları bir kuşak olarak değerlendirmek için yeterli bir unsur olmadığını düşünür. Bireyler içerisinde yaşadıkları dönem ile bağ kuramadığı ve ortak olayları tecrübe etseler bile bir anlam dünyasında buluşturamadıkları sürece kuşak olmak özelliğinden yoksun kalacaklardır. Mannheim kuşakları mekan, güncellik ve kuşak birliği adını verdiği üç temel özellikle tanımlar. Bu tanım içerisinde mekânsal birlik kuşakların aynı tarihsel ve kültürel bağı taşımalar1 açısından önemlidir (Mannheim, 2013, s276-321).

Kuşakları değerlendiren Inglehart (1997), değişen sosyal değerlere odaklanırken sosyo ekonomik koşulların değişiminin kuşakları da değiştirdiğini ve Batıdaki kuşak farkının kökenlerinde de yaşlı kuşağa sunulan refah ve sosyal güvenliğin genç nesillere de aktarılması sonucu genç neslin, yaşlı kuşaklara göre, "kendini ifade etmeyi ve gerçekleştirmeyi" daha değerli bulduğu görülmektedir (Inglehart' dan aktaran Erkenekli vd., 2012, s.36).

Strauss ve Howe (1997), TheFourthTurning" çalışmalarında doğum yıllarına göre kuşak teorilerini sistematikleştirmiştir. Strauss ve Howe, kuşakların sınırları kesin olarak çizebilmek adına inanç, davranışlar, aidiyet algısı ve mekân niteliklerinin ortak olarak bulunması gerektiğini iddia ederler. Strauss ve Howe tarafından oluşturulan kuşak kuraml, dört temel tarihi dönemden oluşmaktadır. Her bir toplumsal dönem, ortalama olarak 15 ve 20 yıllık süreçleri kapsamaktadır. Bu dört dönemin tamamlanması yaklaşık olarak 80-90 yıl kadar sürmekte ve dört aşama tamamlandıktan sonra kendini tekrar yenilemektedir" (Çorum, 2012, s.11). Bu dört aşama; kâhin (prophet), göçebe (nomad), kahraman (hero) ve sanatçı (artist) olarak yazarlar tarafından karakterize edilmişlerdir. Bu karakter tipleri, günümüzde de kullanılan üç önemli kuşağı temsil etmektedir; "Bebek Patlaması Kuşă̆ı", 
"X kuşağı" ve "Y kuşağı". "Ancak kuram, 2005 yılında belirsiz olarak sonlandırılmıştır. Bu nedenle Strauss ve Howe kuramının sistematiğinden yola çıkılarak, 2005 ve sonrası doğan sanatçı kuşağının da bulunduğu batılı kuşak kuramları ortaya çıkmıştır. Bu kuramların sahipleri, sırasıyla Martin ve Tulgan, Oblinger ve Oblinger, Don Tapscott, Zemke ve diğerleridir" (Şalap, 2016, s.16).

Özetle kuşaklar, kavramı tanımlayan ve bir teorik çerçeve içerisinde konumlandıran her bir yorumcu için ortak bir anlatıya konu olan, ortak bir anlatının deneyimleyicisi ve aktarıcısı olan ve ortak bir tarihin bilinci ile ortak bir dönemi ve mekânı paylaşan gruplar olarak tanımlanmışlardır. Dolayısıyla kuşakların her birinin yaşadığı dönem kuşakların ortak bilincine etki etmiştir ve aynı şekilde kuşaklar tarafından şekillendirilmiştir. Bu ortak bilincin oluşması aşamasında en büyük etkenlerden biri ekonomik yapı olarak kabul edilebilir.

Kuşaklar kimi zaman birbirini takip eden kimi zaman ise sıçramalar gösteren ortak bir ekonomik tarihin doğal olarak üretim ve tüketim ilişkilerinin bir parçasıdır. WernerSombart (1912) Burjuva adlı eserinde kuşakların ortak bir ekonomik zihniyetin aktarıcısı oldukların ilk iddia eden Alman sosyal bilimcidir. Sombart kendisinin tarihçilerle ve tarihsel dönemlerle görüş ayrılığının kaynağında her dönemde farklı şekillerde yönlendirilmiş ekonomik öznelerin tarihsel dönemlerle sınırlı olamayacağını belirtir. Sombart: “... ekonomik zihniyet gerçekten de bir kişiden diğerine ve bir dönemden diğerine değişiyorsa, bu durumda belli bir döneme ait zihniyetten ve çeşitli dönemlere özgü ekonomik zihniyetlerin tarihsel dönemlerle sinırlandırılmasindan söz edebilmek mümkün müdür? $\mathrm{O}$ zaman da her dönemde farklı bir şekilde yönlendirilmiş birbirlerinden farklı ve ayrı zihniyetlere sahip ekonomik öznelerin varlığından söz etmek daha doğru olmaz mı?" sorgulamasinı yapar (Sombart, 2008, s.40).

Buradan hareketle kuşaklar ekonomik dönüşümlerin hem aktörü hem de etkilenen nesnesi konumuna gelmektedirler. Dolayısıyla her bir kuşak için ekonomik ve sosyal etkenler tarafından şekillendirilen ortak bir anlattdan söz edebilme imkânı doğmaktadır. Aynı şekilde Sombart, Burjuva adlı kitabında “...bir ekonomik dönemi belirleyen şey onu egemenliği altına almış olan ekonomik sistemdir" derken, kapitalizmin neden Avrupa'da oluştuğu sorusunu yant arayan Weber'in ortak bir ulus bilinci ve diğer 
sosyal etmenler olarak tanımının kuşaklar için de kullanılabilecek bir kavram olarak değerlendirilebilir. (Sombart, 2008, s.76).

Sombart'ın ekonomik belirlenimci yorumunun altında yatan düşünce kuşaklar ve ekonomik ilişkinin devamlılığı konusunda oldukça aydınlatıcıdır. Kuşaklar bulundukları konum gereği kimi zaman birbirlerinden ayrı bir birliktelik sergileseler de onları ve tüm dünyayı birbirine bağlayan ve aynı dönemi yaşamalarıyla oluşmuş ortak bir değerler kümesi bulunmaktadır. Dolayısıyla kendi özel durumunda incelendiklerinde dahi kuşaklar genel bir tarihin parçaları konumundadırlar.

$\mathrm{Bu}$ bilgilerden hareketle kuşak olgusu ayn zamanda değişimi birlikte yaşayan gruplar olarak genellenebilir.

Sosyolojide tüketim olgusu bilindik insanlık tarihinden bu yana var olan bir eylem olarak betimlenebilirken insanlığın yerleşik yaşama geçmeden önce de doğayı tüketmeleriyle başlamıştır ve üretim ilişkilerinin değişim süreçlerine bağlı olarak da değişimler göstermiştir. Ekonomik eylemin merkezinde yer alan tüketim kavramı her bir dönüşüm dönemi içinde yaşayan kuşakları etkisi altına alır ve kuşaklar tarafından etkilenir. Chaney (1999), tüketim alışkanlıklarındaki makro düzeydeki değişimin tüketim yoluyla "ürünlere ve düşüncelere" yansıyarak "kültürün parçası" haline geldiğini "ürünlerin kullanım şekline ve ürünlerle ilişki kurma biçimine ilişkin bu yeni eğilimin, sosyal yapıyı biçimlendirerek kültürün dönüştürülmesine beşiklik ettiğini" belirtir (Chaney'den aktaran Başfırıncı, 2011).

Bu bağlamda dünyada değişen tüketim ilişkileri ve onu kapsayan ekonomik ilişkiler kuşaklar üzerinden ortak kültürel ve zamansal çizgilerle izlenebilir. Kuşaklar hem tüketimi eyler hem de tüketim tarafından değiştirilir. Edgel ve Hetherington da, "sosyal ilişkilerin tüketim deneyimini şekillendirmekte" olduğunu ve bu sürecin sonucunda da " tüketicinin sosyal inşası" nın gerçekleştiğine vurgu yaparak bu görüşü desteklerler (Edgel ve Hetherington, 1996, s.5).

Bu çalışmada kuşakları incelemek tüketicilerin kategorileştirilmesi için gerekli olmasının yanı sıra, kuşakların tüketimde yaşanan değişimlerin tarihsel bir bütün olarak değerlendirmesine de katkı sağlayabilir.

\section{Bebek Patlaması Kuşağı ve Tüketim}

1946-1964 dönemini içeren Bebek Patlaması dönemi adını ikinci dünya savaşından sonra hızla artan nüfustan almıştır. Türkiye ikinci dünya savaşına 
girmese de savaşın çok yakınında bir ülke olarak asker bulundurmak ve savaş ekonomisi uygulamak konumunda kalmıştır. Buna bağlı olarak Türkiye'de o dönemi yaşamış kuşaklar için zor ve sıkıntılı dönemleri beraberinde getirmiştir. Savaş sonrası ekonomik yapıyı güçlendirmek ve üretimi iyileştirmek adına dünyada hızlı bir değişim süreci başlamıştır.

Bu çalışmada bebek patlaması kuşağının Türkiye'ye özgü durumunu anlamak için XX. Yüzyıldan başlamak doğru olacaktır.

Türkiye 1908-1922 yılları arasında, arka arkaya yaşamış olduğu savaşlar ve yıkımlar sebebi ile dünyanın genelinde yaşanan sanayileşme, makineleşme ve kitle üretimi gibi alanlardan görece olarak uzakta kalmıştır. $\mathrm{Bu}$ dönemde Amerika ve Avrupa'nın bir bölümünde yaşanan gelişmeler ve özellikle fordizmin etkisi, ulusal bir kapitalizm, Fordist bir üretim-tüketim modeli yaratılmak istense de, Türkiye'nin yaşadığ üretim ve tüketim ilişkileri üzerinde etkisi zayıf kalmıştır. Yeni cumhuriyet ile Osmanlı'dan alınmış olunan ekonomik miras ve dünyadaki hızlı ekonomik değişimlerle üretim ve tüketimin düzenlenmesi 1920 'lerin sonunda önemli bir hedef olarak tanımlanabilir. Lozan antlaşması, İzmir İktisat Kongresinde sanayileşme kapsamında alınan liberal ekonomi kararları ve çabalarının yerini 1929 büyük buhran sonrasında rafa kaldırılmıştır. Bu süreçte "yerli ve milli burjuvazi" oluşturma çabaları devletin ekonomide aktif rol alarak belirleyici olması söz konusu olmuş ve görece planlı ekonomiye geçilmeye çalışılarak sanayi planları hazırlanmıştır (Keyder, 2001, Boratav, 2005, s.40). Bununla beraber tüm dünyada yaşanan gerilimler nedeniyle sanayide beklenen ölçüde bir gelişme yaşanamamıştır.

1930- 1939 sürecinde başlayan ve en önemli ekonomik politikayı oluşturan korumacilık ve devletçilikle Boratav'ın belirttiği gibi "ilk sanayileşme dönemi" olarak kabul edilebilir (Boratav, 2005, s.59). Büyük buhran, Türkiye için kendi sanayi yapılanmasını oluşturmada çok büyük bir etkiye sahip olmuştur. Kapitalist dünya sisteminin merkezini derinden sarsan 1929 buhranının, bu sistemin bağımlı ve azgelişmiş çevresini oluşturan ülkelerde ilk kez kendi öz dinamikleriyle, ulusal bir sanayileşmeye yönelme fursatı yarattığı, 1950 sonrasında "bağımlılık okulu" adı altında toplanan pek çok çağdaş yazarın benimsediği bir tezdir" (Boratav, 2005, s.65). Türkiye'nin göstermiş olduğu bu atılım ikinci dünya savaşının baş göstermesi ile bir kesintiye uğramiştır. 
İkinci dünya savaşının hemen ardından hem dünyanın yeni dinamikleri ve savaş sonrası yaşanan yıkım hem de kendi içerisinde iç siyaset sorunları ile yeni bir iktisadi döneme girmiştir. Türkiye kendi üretim-tüketim ilişkileri sistemini kurmaya çalıştı̆̆ bu dönemlerde, sürekli olarak yaşanan değişimlerden etkilenmiştir. 1930'lu yıllarda başlayıp 1946 yılına kadar süren dişa kapalı ve devlet tarafından korunan bu dönemi Boratav, dış denge merkezli ve "içe dönük iktisat politikaları"nun yavaş yavaş terkedildiği bir dönem olarak açıklar (Boratav, 2005, s.94).

1947 yılında Marshall Planı'nın Türkiye'yi de kapsamasıyla birlikte tarımsal kredi ile alınan tarım araçları sayesinde kırsal kesimde bir hareketlilik sağlanmıştır. $\mathrm{O}$ dönemde ürünler dış pazarlardan alıcı bulurken, bir yandan da pazarı genişletici bir yol politikası ile karayolları yapımına ağırlık verilmiş ve kentler ile köyler arasında ulaşım yolları kurulmuştur.

1961 yılına kadar olan dönemi Boratav (2005), “... korumacı, iç pazara dönük ve ithal ikameci görüntüsüyle 1930'lu yıllarda bilinçli olarak başlattlan yaygın tüketim mallarında ithal ikamesi 1954 sonrasının dış tıkanma koşullarında zorunlu olarak sürdürülmüsş" olduğunu belirtir (Boratav, 2005, s.118).

1960'larda ekonomi politikalarında köklü değişikliklere gidilmiştir. Devlet Planlama Teşkilatı'nın (DPT) kurulması ile birlikte 1963 yılında uygulanmaya başlanan birinci Beş Yıllık Kalkınma Planı'nda Pamuk'a göre "ekonominin rotası iç pazara yönelik sanayileşme yönünde" oluşturulmuştu (Pamuk, 2018, s.235).

Türkiye Birinci Dünya Savaşı öncesinde başlamış olduğu bir takım ekonomik reform ve yapılaşma hareketlerini dünyanın 1950'lere kadar yaşamış olduğu yoğun dönem yüzünden istediği anlamda ortaya koymayı başaramamıştır. Dolayısıyla Bebek Patlaması Kuşağı tüm dünya ile oldukça benzer koşullar içerisinde Türkiye'de yaşamıştır. Özellikle "savaş ekonomisi" olarak adlandırılan yıllar ve devamında sürece damga vuran Marshall Planı bu kuşağın birçok farklı ekonomik yapıyı bir arada deneyimlemesine sebep olmuştur. Dış koşulların iç koşulları yönlendirmesi, kıtlık ekonomisi, tüketimin daha çok iç pazarla sınırlı kaldığı kendi kendine yetme süreçleri nedeniyle bu dönem kuşağı dünya genelinde benzerlik göstermektedir. 


\section{Kuşă̆ı ve Tüketim}

1965-1979 dönemlerini kapsayan X kuşağı, Türkiye'de yeni bir dönem olan "ithal ikameci" sanayileşme politikası ile büyümüştür. Bu dönemde, özel teşebbüslere devlet desteği ve yeniden tahsis edilmeye çalsşlan üretimtüketim ilişkileri damga vurmuştur. Boratav (2005) bu dönemin, "İthal ikamesi süreci, iç pazarın genişliği ve canlılığ üzerine inşa edilmiş" olduğunu belirtir (Boratav, 2005, s.124). Türkiye'nin dünya ekonomik sürecine eklemlenmesinde yaşanılan bu gelişme kendi iç dinamiği bakımından oldukça farklidır. Pamuk (2018), ekonomide devletin etkin bir rol oynamaya devam ettiğini ancak karma ekonomi modelinin geçerli olduğu 1960'larda, "kamu kesimi ile özel kesim arasında yeni bir iş bölümü" oluşmaya başladığını iddia eder (Pamuk, 2018, s.237).

Türkiye'de yaşanan bu gelişmelerin yanı sıra, İkinci Dünya Savaşından sonra, üretimde, hızlı bir ivme gösteren Avrupa ülkelerinde işçi açığı ortaya çıkmıştır. Bu dönemde Türkiye'den Avrupa'ya işçi göçleri başlamıştır. İşçi göçleri ile birlikte Türkiye, Avrupa pazarı ile tam anlamıyla bir tanışma gerçekleştirmiş ve tüketim ilişkileri de buna bağlı olarak hılı bir değişme göstermiş̧ir. Keyder'in de belirttiği gibi köy ve kentlerden yurt dışına göç hızlanması "modern anlamda tüketim kültürü ve modern yaşam tarzı ile gerçek bir tanışma" ya neden olmuştur. Göç edenler de "yeni yaşam tarzlarını" köy ve kentlere taşıyarak "işçi dövizleri ve Almanya' dan getirdikleri metalar yeni tüketim kalıbının kasabalar ve köylere kadar yayılmasını" sağlamıştır. Göçmenlerle birlikte ortaya çıkan yeni yaşam tarzı "dayanıklı tüketim mallarıyla, yeni tüketim alışkanlıklarının göstergesi olmuştur (Keyder, 2001, s.252).

1960'l y yllardan başlayan ve 1970'li yılların sonuna kadar devam eden ekonomik iyileşmeden Türkiye özellikle tüketim anlamında büyük bir değişim yaşamış ve dünya ile paralel bir çizgiye oturmayı neredeyse başarmıştır. "Türkiye'de açlan yabancı şirketlerin şubeleriyle Batılı tüketim ürünlerine ulaşmak kolaylaşmış, tüketim ihtiyaçları yeniden belirlenmeye başlanmıştır. Buzdolabı, televizyon, çamaşır makinesi gibi nesneler zorunlu ihtiyaçlar arasında yerlerini almıştır. Türkiye'de kentlerden kırsal kesimde yaşayanlara kadar artık herkes tüketimin bir öznesi haline gelmiştir" (Aydemir, 2006, s.209). Ancak 1970 yllında Amerika'dan tüm dünyaya yayılan 
ekonomik krizler, ekonomik ambargolar ve petrol krizleri 1960'larda başlayan refahın önünü kesmiştir.

Bebek Patlaması kuşağını takip eden X Kuşağı dönemi Türkiye için bir ihtilalle başlamıştır. Aynı şekilde X Kuşağını takip eden Y Kuşağı için de yeni dönem bir darbe ile açılmıştır. 1970'li yılların ortalarından itibaren gelişen olumsuz ekonomik koşullar, Türkiye'nin siyasi havasını da derinden etkilemiştir ve ülke içi çatışmalar kontrol edilemez bir hale gelmiştir. 24 Ocak 1980 Kararları "karaborsayı önlemek, piyasayı yeniden normal işleyişine" kavuşturabilmek için yeni bir ekonomik planı uygulamaya girmiştir (Eğilmez, 2018, s.147).

\section{Y Kuşağı ve Tüketim}

1980-1999 yılların içeren bu evre, dünyada ortaya çıan "tüketim merkezli" ve pazarın genişlemesine yol açarak ekonomide izlemiş olduğu, 'devletçilik' ve 'korumacllı' gibi yöntemleri bırakmasına neden olarak Türkiye'nin küresel ekonomiye eklemlenmesini sağladı. 1980'li ylllar hem ekonominin hem de üretim-tüketim ilişkileri dengesinin değiştiği yıllar olarak kabul edilebilir. Boratav (2005), Türkiye'nin izlemiş olduğu dış ticaret politikasının özgün bir üretim-tüketim ilişkisi oluşturmak bakımından oldukça yetersiz hatta engelleyici olduğunu iddia eder. Türkiye'nin yaşamış olduğu hızlı değişim ve dünyaya açılma, üretim ilişkileri ekseninde bir kaymaya sebep olmuştur (Boratav, 2005, s.162). Sanayi sektörü 1980'li yıllardan sonra, dişa açılmanın etkisi ile verimliliğini kaybetmiştir. Bu süreçte inşaat ve hizmet sektörleri ekonomiyi sürükleyen alanlar olmuştur.

1980'li y1llardan sonra dünya genelinde neoliberal politikaların hâkim hale gelmesi ile dünyaya açılma politikaları üretim-tüketim ilişkilerinde dengesiz bir dağılım oluşturmuş ve oluşturmaya devam etmektedir. Üretim-tüketim ilişkilerinde üretimin ucuz işgücü piyasalarına ve uzak doğuya kayması ile birlikte geniş bir tüketici sınıf ortaya çıkmıştır.

Buradan hareketle, Türkiye'nin son yüz yılda kendi ürettiğini tüketen bir toplum ideali, dişa açlma ve küreselleşmenin etkisiyle, üretmeden tüketen bir topluma dönüşmesi bu çalışmada önemli bir hareket noktasıdır. Dolay1syyla, üretim-tüketim ilişkilerinin sosyal ve ekonomik boyutunu da göz önüne alarak, kuşaklara etkisini anlamak bu çalışmanın amacını oluşturmaktadır. 


\section{Yöntem}

$\mathrm{Bu}$ araştırma tüketim ilişkilerini tarihsel bir perspektiften üretimi dışlamaksızın anlamayı ve kuşakların üretim- tüketim ilişkilerinin tarihsel sürekliliğini, değişen yaşam evreleri üzerinden dönemselleştirmeyi amaçlamaktadır.

Araştırmanın evreni, İstanbul'da ikamet eden Bebek Patlaması, $X$ ve $Y$ kuşaklarında bulunan kişilerin tamamını kapsamaktadır. Bununla beraber araştırmanın evreninin tanımlanası araştırmanın sınırlarını belirleyecek olan örneklemin ortaya koyabilmesi açısından ilk adımı oluşturmaktadır. "Örneklem, belli kurallara göre, belli bir evrenden seçilmiş ve seçildiği evreni temsil yeterliği kabul edilen küçük kümedir. Araştırmalar çoğunlukla örneklem kümeler üzerinde yapılır ve elde edilen sonuçlar ilgili evrenlere genellenir." (Karasar, 2005, s. 110-111).

Bu doğrultuda araştırmanın örneklemi küme örneklemesi tekniği kullanılarak belirlenmiştir. Küme örneklemesi tekniği olasılıklı örneklem teknikleri içerisinde yer almaktadır. Kolay ulaşılabilirlik ve zaman açısından tercih edilen bir teknik olmakla birlikte aralarında coğrafi uzaklıklar bulunan ve evren olarak çok geniş bir kitleyi kapsayan araştırmalar için kullanılmaktadır. Örnekleme giren kümeler içinden belirli sayıda birey, basit, tesadüfi ya da tabakalı örnekleme yoluyla seçilir. Bir küme, örnekleme unsurlarını, yani örnekleme seçeceğimiz birimleri kapsar ancak kümelerin kendileri geçici örnekleme unsurlarıdır (Neuman, 2019, s.340). Farklı sosyo-ekonomik 3 kuşaktan 180 katılımcı ile oluşturulan anket uygulanmıştır. Bu katılımcılar sosyo-ekonomik statüleri temelinde seçilerek kuşak, cinsiyet ve SES (sosyoekonomik statü) dikkate alınmıştır. Her bir kuşaktan 30 kadın ve 30 erkek katılımcı ile yine her cinsiyet grubu içerisinden 10 alt, 10 orta ve 10 üst sosyo-ekonomik statü grubuna dahil katılımclara anket uygulanmıştır.

Anket hazırlanırken araştırmanın merkezi tüketim kavramı üzerinden oluşturulmuştur. İkinci kavram, tüketim ilişkilerini daha anlaşılabilir kılmak adına, özellikle tarihsel bir perspektiften ve bir arka plan okuması olarak kullanılan üretim kavramıdır. Üçüncü olarak ise çalışmanın evrenini ve inceleme odağını oluşturan kuşak kavramı gelmektedir. Kuşak kavramı, değişen üretim tüketim ilişkilerinin tarihsel sürekliliğini, değişen yaşam evreleri üzerinden gözlemleyebilme ve daha önemlisi belirli dönemselleştirmelere imkân tanıması bakımından oldukça önemli bir noktada yer almiştır. 
Kuşaklararası tüketim ilişkilerine odaklanan çalışmanın sorusu Türkiye'de yaşanan sosyo-ekonomik süreçler farklı kuşaktan ve sosyoekonomik arka plandan bireyler tarafından nasıl algılanmıştır/algılanmaktadır olarak belirlenmiştir. Bu temel soruya yanıt ararken araştırmada kuşakların tüketime ilişkin tutum ve farklılıklarını belirlemek adına öncül araştırma soruları ve hipotezler oluşturulmuştur;

1- Üç kuşağın yaşam pratikleri içerisinde tüketim rolü nasıl bir değişim göstermiştir?

2- Kuşaklar arasında tüketimin önemi ve gündelik hayatlarındaki işlevi açısından farklılıklar var mıdır?

3- Kuşaklararasında lüks tüketime ilişkin tutum hangi ürün ve hizmetler açısından değişiklik göstermektedir?

4- Marka ve tüketim ilişkisi kuşaklararasında nasıl farklılaşmaktadır?

5- Dünya ve Türkiye arasında tüketim ilişkilerinin seyri bakımından nasıl bir birliktelik ya da farlılık ilişkisi bulunabilir?

Veri analizi sürecinde ise toplanan anketler SPSS 25.0 programı kullanılarak incelenmiş ve tablolaştırılmıştır.

\section{Bulgular}

\section{Tablo 1. Demografik Özellikler Tablosu}

\begin{tabular}{lll}
\hline Kuşakların Dağılımı & $N$ & $\%$ \\
\hline Bebek Patlaması Kuşă̆ı & 60 & $\% 33,3$ \\
\hline X Kuşă̆1 & 60 & $\% 33,3$ \\
\hline Y Kuşă̆ı & 60 & $\% 33,3$ \\
\hline Toplam & 180 & $\% 100$ \\
\hline Cinsiyet & $N$ & $\%$ \\
\hline Erkek & 90 & $\% 50$ \\
\hline Kadın & 90 & $\% 50$ \\
\hline Toplam & 180 & $\% 100$ \\
\hline Medeni Hal & $N$ & $\%$ \\
\hline Evli & 105 & $\% 58,3$ \\
\hline Bekâr & 54 & $\% 30,0$ \\
\hline Dul & 14 & $\% 7,8$ \\
\hline Ayrilmış & 7 & $\% 3,9$ \\
\hline Toplam & 180 & $\% 100$ \\
\hline Eğitim & $N$ & $\%$ \\
\hline Ilkokul ve Ortaokul & 21 & $\% 11,8$ \\
\hline Lise & 44 & $\% 24,4$ \\
\hline Yüksek Okul & 17 & $\% 99,4$ \\
\hline Üniversite & 76 & $\% 42,2$ \\
\hline Yüksek Lisans/Doktora & 22 & $\% 12,2$ \\
\hline
\end{tabular}




\begin{tabular}{lll}
\hline Toplam & 180 & $\% 100$ \\
\hline Meslek & $N$ & $\%$ \\
\hline Beyaz Yakalı Çalışan & 50 & $\% 27,8$ \\
\hline Mavi Yakalı Çalışan & 9 & $\% 5$ \\
\hline Memur & 24 & $\% 13,3$ \\
\hline Ev Hanımı & 22 & $\% 12,2$ \\
\hline Serbest Meslek & 34 & $\% 18,9$ \\
\hline Sanatkâr & 4 & $\% 2,2$ \\
\hline İşveren & 5 & $\% 2,8$ \\
\hline Diğer & 32 & $\% 17,8$ \\
\hline Toplam & 180 & $\% 100$ \\
\hline Tablo 2. Katılımcıların Maddi Durumlarını Değerlendirme Tablosu & \\
\hline Maddi Durum Nasıl? & $N$ & $\%$ \\
\hline İyi & 41 & $\% 22,8$ \\
\hline Orta & 120 & $\% 66,7$ \\
\hline Kötü & 19 & $\% 10,6$ \\
\hline Toplam & 180 & $\% 100$ \\
\hline
\end{tabular}

Ankette 180 katılımcının yarısından fazlası $(\% 58,3)$ evli ve yarısına yakının $(\% 42,2)$ üniversite mezunudur. Katılımcların meslek gruplarında ise dengeli bir dağılım olduğu gözükmektedir. En yoğun meslek grubu \%27,8 ile beyaz yakalı çalışanlar olarak saptanmıştır.

Tablo 3. Bebek Patlaması, X ve Y Kuşaklarının Harcamaların Nelere Ayırdıkları

\begin{tabular}{|c|c|c|c|c|c|c|}
\hline & \multicolumn{2}{|c|}{$\begin{array}{l}\text { Bebek } \\
\text { Patlaması- Kuşağ1 }\end{array}$} & \multicolumn{2}{|c|}{ X-Kuşağ1 } & \multicolumn{2}{|c|}{ Y-Kuşağ1 } \\
\hline & $N$ & $\%$ & $N$ & $\%$ & $N$ & $\%$ \\
\hline $\begin{array}{l}\text { Yiyecek- } \\
\text { İçecek/Zorunlu } \\
\text { Harcamalar }\end{array}$ & 58 & $41,10 \%$ & 57 & $26,30 \%$ & 57 & $23,80 \%$ \\
\hline Eğlence Harcamaları & 10 & $7,10 \%$ & 22 & $10,10 \%$ & 37 & $15,50 \%$ \\
\hline $\begin{array}{l}\text { Giyim-Kuşam } \\
\text { Harcamaları }\end{array}$ & 32 & $22,70 \%$ & 35 & $16,10 \%$ & 50 & $20,90 \%$ \\
\hline Başkalarına Yardım & 17 & $12,10 \%$ & 14 & $6,50 \%$ & 12 & $5,00 \%$ \\
\hline Eğitim Harcamaları & 3 & $2,10 \%$ & 37 & $17,10 \%$ & 21 & $8,80 \%$ \\
\hline Kira Harcamaları & 5 & $3,50 \%$ & 15 & $6,90 \%$ & 22 & $9,20 \%$ \\
\hline Borç Harcamaları & 10 & $7,10 \%$ & 21 & $9,70 \%$ & 23 & $9,60 \%$ \\
\hline Yatırım & 6 & $4,30 \%$ & 16 & $7,40 \%$ & 17 & $7,10 \%$ \\
\hline Toplam & 100 & & 100 & & 100 & \\
\hline
\end{tabular}

Katılımcılardan Bebek Patlaması kuşağının önceliğinin temel ihtiyaçları (yiyecek-içecek ve giyim-kuşam), için harcama yapmak yönünde olduğunu $X$ ve $Y$ kuşağına mensup katılımcılar belirtmiştir. Bebek Patlaması Kuşağ \%41,1 ile Yiyecek-İçecek harcamasına ve \%22,7 ile Giyim-kuşam harcaması- 
na en büyük payı ayıran kuşaktır. Bebek Patlaması kuşağının başkalarına yardıma diğer kuşaklara nazaran \%12,1 ile büyük bir pay ayırmaktadır. Y kuşağı, diğer kuşaklara nazaran eğlenceye $\% 15,5$ pay ayırmaktayken, $X$ kuşağındaki katılımcların yaş itibariyle çocuk sahibi olmaları göz önüne alındığında en çok \%17,1 gibi bir payı eğitime ayırmaktadırlar. Y kuşağındaki katılımcıların kira için harcadıkları miktar diğer kuşaklara gör daha fazladır.

Tablo 4. Bebek Patlaması, X ve Y Kuşaklarının Günlük Tüketim Alışkanlıkları (Yüzdelik hesaplamalar her bir kategorinin değerleri içerisinde hesaplanmıştır)

\begin{tabular}{lllllll}
\hline & \multicolumn{2}{l}{ Kredi Kart1 } & \multicolumn{2}{c}{ Cep Telefonu } & \multicolumn{2}{c}{ Dizüstü Bilgisayar } \\
\cline { 2 - 7 } & $N$ & $\%$ & $N$ & $\%$ & 24 & $\%$ \\
\hline $\begin{array}{l}\text { Bebek } \\
\begin{array}{l}\text { Patlaması } \\
\text { Kuşağ1 }\end{array}\end{array}$ & 37 & $27,4 \%$ & 59 & $33,1 \%$ & $24,0 \%$ \\
\hline X Kuşağı & 51 & $37,8 \%$ & 59 & $33,1 \%$ & 30 & \\
\hline Y Kuşağ1 & 47 & $34,8 \%$ & 60 & $33,8 \%$ & 46 & $46,0 \%$ \\
\hline Toplam & 135 & $100 \%$ & 178 & $100 \%$ & 100 & $100 \%$ \\
\hline
\end{tabular}

Kuşakların Kredi Kartı, Cep Telefonu ve Dizüstü Bilgisayar Sahiplik Oranlarn

Kredi kartı ve dizüstü bilgisayara sahip olma oranları $X$ ve $Y$ kuşakları için bebek patlaması kuşağına mensup bireyleri geride bırakırken, cep telefonunun tüm kuşaklar için artık bir olmazsa olmaz halini aldığı gözlemlenmektedir. Y kuşağına mensup bireyler \%46'lık bir oran ile dizüstü bilgisayara sahip olma konusunda diğer kuşakların oldukça üstünde yer alırken kredi kartı sahipliği konusunda bebek patlaması kuşağ $\% 27,4$ ile en alt sırada yer almaktadır.

Tablo 5. Bebek Patlaması, X ve Y Kuşaklarının Günlük Tüketim Alışkanlıklan (Yüzdelik hesaplamalar "Katılıyorum", "Katılmıyorum" ve "Kararsızım" seçeneklerinin her birindeki özgün dağılıma göre gösterilmiştir)

Evimde Uydu Bulunur

\begin{tabular}{llllll} 
& & Katıllyorum & Katılmıyorum & \multicolumn{1}{c}{ Total } \\
\hline \multirow{2}{*}{ Bebek-Patlaması Kuşağı } & $\mathrm{N}$ & 49 & 11 & 60 \\
\cline { 2 - 5 } & $\%$ & $81,7 \%$ & $18,3 \%$ & $100,0 \%$ \\
\hline \multirow{2}{*}{ X-Kuşağ1 } & $\mathrm{N}$ & 43 & 17 & 60 \\
\hline Y-Kuşağ1 & $\%$ & $71,7 \%$ & $28,3 \%$ & $100,0 \%$ \\
\hline
\end{tabular}




\begin{tabular}{|c|c|c|c|c|c|}
\hline & $\%$ & $78,3 \%$ & & $21,7 \%$ & $100,0 \%$ \\
\hline \multirow[t]{2}{*}{ Total } & $\mathrm{N}$ & 139 & & 41 & 180 \\
\hline & $\%$ & $77,2 \%$ & & $22,8 \%$ & $100,0 \%$ \\
\hline \multicolumn{6}{|c|}{ Netflix ya da Diğer Online Platformlara Üyeyim } \\
\hline & & Katıliyorum & Kararsizım & Katilmiyorum & Total \\
\hline \multirow[t]{2}{*}{ Bebek-Patlaması Kuşağı } & $\mathrm{N}$ & 9 & 47 & 4 & 60 \\
\hline & $\%$ & $15,0 \%$ & $78,3 \%$ & $6,7 \%$ & $100,0 \%$ \\
\hline \multirow{2}{*}{ X-Kuşağg1 } & $\mathrm{N}$ & 22 & 37 & 1 & 60 \\
\hline & $\%$ & $36,7 \%$ & $61,7 \%$ & $1,7 \%$ & $100,0 \%$ \\
\hline \multirow{2}{*}{ Y-Kuşağı } & $\mathrm{N}$ & 33 & 25 & 2 & 60 \\
\hline & $\%$ & $55 \%$ & $47,1 \%$ & $3,3 \%$ & $100,0 \%$ \\
\hline \multirow[t]{2}{*}{ Total } & $\mathrm{N}$ & 64 & 109 & 7 & 180 \\
\hline & $\%$ & $35,6 \%$ & $60,6 \%$ & $3,9 \%$ & $100,0 \%$ \\
\hline \multicolumn{6}{|l|}{ Günlük Gazete Takip Ederim } \\
\hline & & Katiliyorum & Kararsızım & Katilmiyorum & Total \\
\hline \multirow[t]{2}{*}{ Bebek-Patlaması Kuşağı } & $\mathrm{N}$ & 40 & 18 & 2 & 60 \\
\hline & $\%$ & $66,7 \%$ & $30,0 \%$ & $3,3 \%$ & $100,0 \%$ \\
\hline \multirow{2}{*}{ X-Kuşağı } & $\mathrm{N}$ & 33 & 23 & 4 & 60 \\
\hline & $\%$ & $55,0 \%$ & $38,3 \%$ & $6,7 \%$ & $100,0 \%$ \\
\hline \multirow{2}{*}{ Y-Kuşağı } & $\mathrm{N}$ & 12 & 42 & 6 & 60 \\
\hline & $\%$ & $20 \%$ & $70 \%$ & $10 \%$ & $100,0 \%$ \\
\hline \multirow[t]{2}{*}{ Total } & $\mathrm{N}$ & 85 & 83 & 12 & 180 \\
\hline & $\%$ & $47,2 \%$ & $46,1 \%$ & $6,7 \%$ & $100,0 \%$ \\
\hline \multicolumn{6}{|c|}{ Gazeteleri İnternet Üzerinden Takip Ederim } \\
\hline & & Katıliyorum & Kararsizım & Katılmiyorum & Total \\
\hline \multirow[t]{2}{*}{ Bebek-Patlaması Kuşağı } & $\mathrm{N}$ & 21 & 36 & 3 & 60 \\
\hline & $\%$ & $35,0 \%$ & $60,0 \%$ & $5,0 \%$ & $100,0 \%$ \\
\hline \multirow{2}{*}{ X-Kuşağı } & $\mathrm{N}$ & 43 & 14 & 3 & 60 \\
\hline & $\%$ & $71,7 \%$ & $23,3 \%$ & $5,0 \%$ & $100,0 \%$ \\
\hline \multirow{2}{*}{ Y-Kuşağg } & $\mathrm{N}$ & 43 & 14 & 3 & 60 \\
\hline & $\%$ & $71,7 \%$ & $23,3 \%$ & $5,0 \%$ & $100,0 \%$ \\
\hline \multirow[t]{2}{*}{ Total } & $\mathrm{N}$ & 107 & 64 & 9 & 180 \\
\hline & $\%$ & $59,4 \%$ & $35,6 \%$ & $5,0 \%$ & $100,0 \%$ \\
\hline
\end{tabular}

Her üç kuşak için de evinde uydu ve/veya Digitürk vb. televizyona yönelik yayın araçlarının bulunma oranı birbirlerine yakın seyretmektedir. Bununla beraber anketin önceki sorularına uyumlu bir şekilde Netflix gibi online aboneliklerde bebek patlaması kuşağı 14,1\% ile en az sahiplik oranı belirtirken, $X$ kuşağ $134,4 \%$ ile ondan daha fazla ve en yüksek oran $51,6 \%$ ile Y kuşağ1 mensubu bireylerde görülmektedir. Benzer bir şekilde "evimde internet vardır" sorusu için en düşük cevabı \%27,0 ile Bebek Patlaması kuşağı vermiştir. Evcil hayvana sahip olma konusunda ise kuşaklararası yakın oranlara rağmen Bebek Patlaması kuşağı \%42,9 ile çoğunlukta bulunmaktadır. Günlük basılı gazete takip etme oranları Bebek patlamasından \%47.1 ile 
Y kuşağında \%14,1 oranına kadar belirgin bir düşüş göstermektedir. Tam karşıt olarak internetten gazete takip etme oranları ise $\mathrm{Y}$ kuşağından \%40,2 ile Bebek Patlaması kuşağında \%19,6 oranına gerilemiştir.

Tablo 6. Kuşakların Lüks Tüketim Alışkanlıkları-1 (Yüzdelik hesaplamalar "Katılıyorum", "Katılmıyorum" ve "Kararsızım" seçeneklerinin her birindeki özgün dağılıma göre gösterilmiştir

\begin{tabular}{|c|c|c|c|c|c|}
\hline \multicolumn{6}{|c|}{ Alışveriş Yaparken En Ucuzunu Alırım } \\
\hline & & Katiliyorum & Kararsızım & Katilmiyorum & Total \\
\hline \multirow[t]{2}{*}{ Bebek-Patlaması Kuşağı } & $\mathrm{N}$ & 18 & 12 & 30 & 60 \\
\hline & $\%$ & $30,0 \%$ & $20,0 \%$ & $50,0 \%$ & $100,0 \%$ \\
\hline \multirow{2}{*}{ X-Kuşağ1 } & $\mathrm{N}$ & 15 & 13 & 32 & 60 \\
\hline & $\%$ & $25,0 \%$ & $21,7 \%$ & $53,3 \%$ & $100,0 \%$ \\
\hline \multirow{2}{*}{ Y-Kuşağı } & $\mathrm{N}$ & 14 & 16 & 30 & 60 \\
\hline & $\%$ & $23,3 \%$ & $26,7 \%$ & $50,0 \%$ & $100,0 \%$ \\
\hline \multicolumn{6}{|c|}{ Fiyatı Yükseldikçe Daha Kaliteli Ürünler Olduğunu Düşünürüm } \\
\hline & & Katiliyorum & Kararsızım & Katilmiyorum & Total \\
\hline \multirow[t]{2}{*}{ Bebek-Patlaması Kuşağı } & $\mathrm{N}$ & 23 & 12 & 25 & 60 \\
\hline & $\%$ & $38,3 \%$ & $20,0 \%$ & $41,7 \%$ & $100,0 \%$ \\
\hline \multirow{2}{*}{ X-Kuşağı } & $\mathrm{N}$ & 19 & 9 & 32 & 60 \\
\hline & $\%$ & $31,7 \%$ & $15,0 \%$ & $53,3 \%$ & $100,0 \%$ \\
\hline \multirow{2}{*}{ Y-Kuşağ1 } & $\mathrm{N}$ & 10 & 17 & 33 & 60 \\
\hline & $\%$ & $16,7 \%$ & $28,3 \%$ & $55,0 \%$ & $100,0 \%$ \\
\hline \multicolumn{6}{|c|}{ İyi Bir Taklit Ürün Bulursam Orijinali Yerine Altrm } \\
\hline & & Katiliyorum & Kararsızım & Katilmiyorum & Total \\
\hline \multirow[t]{2}{*}{ Bebek-Patlaması Kuşağı } & $\mathrm{N}$ & 35 & 4 & 21 & 60 \\
\hline & $\%$ & $58,3 \%$ & $6,7 \%$ & $35,0 \%$ & $100,0 \%$ \\
\hline \multirow{2}{*}{ X-Kuşağı } & $\mathrm{N}$ & 26 & 11 & 23 & 60 \\
\hline & $\%$ & $43,3 \%$ & $18,4 \%$ & $38,3 \%$ & $100,0 \%$ \\
\hline \multirow{2}{*}{ Y-Kuşağ1 } & $\mathrm{N}$ & 27 & 6 & 27 & 60 \\
\hline & $\%$ & $45,0 \%$ & $45,0 \%$ & $10,0 \%$ & $100,0 \%$ \\
\hline \multicolumn{6}{|c|}{ İyi Bir Taklit Ürün Bulursam Orijinali Yerine Alrrm } \\
\hline & & Katiliyorum & Kararsızım & Katılmiyorum & Total \\
\hline \multirow[t]{2}{*}{ Bebek-Patlaması Kuşağı } & $\mathrm{N}$ & 35 & 4 & 21 & 60 \\
\hline & $\%$ & $58,3 \%$ & $6,7 \%$ & $35,0 \%$ & $100,0 \%$ \\
\hline \multirow{2}{*}{ X-Kuşağı } & $\mathrm{N}$ & 26 & 11 & 23 & 60 \\
\hline & $\%$ & $43,3 \%$ & $18,4 \%$ & $38,3 \%$ & $100,0 \%$ \\
\hline \multirow{2}{*}{ Y-Kuşağı } & $\mathrm{N}$ & 27 & 6 & 27 & 60 \\
\hline & $\%$ & $45,0 \%$ & $45,0 \%$ & $10,0 \%$ & $100,0 \%$ \\
\hline \multicolumn{6}{|c|}{ Markalara Sahip Olmak Iyi Hissettirir } \\
\hline & & Katiliyorum & Kararsızım & Katılmiyorum & Total \\
\hline \multirow[t]{2}{*}{ Bebek-Patlaması Kuşağı } & $\mathrm{N}$ & 32 & 2 & 26 & 60 \\
\hline & $\%$ & $53,3 \%$ & $3,4 \%$ & $43,3 \%$ & $100,0 \%$ \\
\hline \multirow{2}{*}{ X-Kuşağ } & $\mathrm{N}$ & 24 & 6 & 30 & 60 \\
\hline & $\%$ & $40,0 \%$ & $10,0 \%$ & $50,0 \%$ & $100,0 \%$ \\
\hline \multirow{2}{*}{ Y-Kuşağı } & $\mathrm{N}$ & 37 & 8 & 15 & 60 \\
\hline & $\%$ & $61,7 \%$ & $13,3 \%$ & $25,0 \%$ & $100,0 \%$ \\
\hline
\end{tabular}


Bebek Patlaması Kuşağına mensup bireyler bir ürünün en ucuzu alma konusunda \%38,3'lük ile diğer kuşaklara göre daha esnek bir tutum sergilemedirler. Bu oran kademeli olarak düşüş göstermektedir. En düşük noktası olan Y Kuşağında \%29,8'e kadar gerilemiştir. Bunun tersi bir şekilde Bebek Patlaması Kuşağı bir ürünün fiyatının yükseldikçe daha kaliteli olacağını, \%44,2'lik bir oran ile en çok düşünen kuşak olarak gözükmektedir. Markaların iyi bir taklidini kullanmak konusunda Bebek Patlaması kuşağı en esnek tutumu sergilemektedir. Markaların, kullanan kişileri iyi hissettireceği konusunda ise $Y$ Kuşağ $1 \% 39,8^{\prime}$ lik bir oran ile bu düşünceye en çok katılan kuşak olmuştur.

Tablo 7. Kuşakların Lüks Tüketim Alışkanlıkları-2 (Yüzdelik hesaplamalar "Katılıyorum", "Katılmıyorum" ve "Kararsızım" seçeneklerinin her birindeki özgün dağılıma göre gösterilmiştir)

\begin{tabular}{|c|c|c|c|c|c|}
\hline \multicolumn{6}{|l|}{ Markalar Lüzumsuzdur } \\
\hline & & Katiliyorum & Kararsizım & Katılmiyorum & Total \\
\hline \multirow[t]{2}{*}{ Bebek-Patlaması Kuşağı } & $\mathrm{N}$ & 15 & 9 & 36 & 60 \\
\hline & $\%$ & $25,0 \%$ & $15,0 \%$ & $60,0 \%$ & $100,0 \%$ \\
\hline \multirow{2}{*}{ X-Kuşağı } & $\mathrm{N}$ & 6 & 19 & 35 & 60 \\
\hline & $\%$ & $10,0 \%$ & $31,7 \%$ & $58,3 \%$ & $100,0 \%$ \\
\hline \multirow{2}{*}{ Y-Kuşağ1 } & $\mathrm{N}$ & 11 & 28 & 21 & 60 \\
\hline & $\%$ & $18,3 \%$ & $35,0 \%$ & $46,7 \%$ & $100,0 \%$ \\
\hline \multicolumn{6}{|c|}{ Arkadaşlarmmda Gördü̈̆̈̈m Bir Markayı Ben de İsterim } \\
\hline & & Katiliyorum & Kararsızım & Katilmiyorum & Total \\
\hline \multirow[t]{2}{*}{ Bebek-Patlaması Kuşağı } & $\mathrm{N}$ & 10 & 1 & 49 & 60 \\
\hline & $\%$ & $10,7 \%$ & $1,6 \%$ & $81,7 \%$ & $100,0 \%$ \\
\hline \multirow{2}{*}{ X-Kuşağı } & $\mathrm{N}$ & 6 & 49 & 5 & 60 \\
\hline & $\%$ & $10,0 \%$ & $8,3 \%$ & $81,7 \%$ & $100,0 \%$ \\
\hline \multirow{2}{*}{ Y-Kuşağı } & $\mathrm{N}$ & 11 & 12 & 37 & 60 \\
\hline & $\%$ & $18,3 \%$ & $20,0 \%$ & $61,7 \%$ & $100,0 \%$ \\
\hline \multicolumn{6}{|c|}{ Ünlü Markalar Toplumun Üst Kesimini Yansittr } \\
\hline & & Katiliyorum & Kararsızım & Katılmıyorum & Total \\
\hline \multirow[t]{2}{*}{ Bebek-Patlaması Kuşağı } & $\mathrm{N}$ & 31 & 5 & 24 & 60 \\
\hline & $\%$ & $51,7 \%$ & $8,3 \%$ & $40,0 \%$ & $100,0 \%$ \\
\hline \multirow{2}{*}{ X-Kuşağı } & $\mathrm{N}$ & 20 & 12 & 28 & 60 \\
\hline & $\%$ & $33,3 \%$ & $20,0 \%$ & $46,7 \%$ & $100,0 \%$ \\
\hline \multirow{2}{*}{ Y-Kuşağı } & $\mathrm{N}$ & 21 & 11 & 28 & 60 \\
\hline & $\%$ & $35,0 \%$ & $18,3 \%$ & $46,7 \%$ & $100,0 \%$ \\
\hline \multicolumn{6}{|c|}{ Satın Almadan Önce Başkalarınn Düşüncelerine Önem Veririm } \\
\hline & & Katiliyorum & Kararsızım & Katılmiyorum & Total \\
\hline \multirow[t]{2}{*}{ Bebek-Patlaması Kuşağı } & $\mathrm{N}$ & 38 & 6 & 16 & 60 \\
\hline & $\%$ & $63,3 \%$ & $10,0 \%$ & $26,7 \%$ & $100,0 \%$ \\
\hline X-Kuşağ1 & $\mathrm{N}$ & 37 & 7 & 16 & 60 \\
\hline
\end{tabular}




\begin{tabular}{llllll}
\hline & $\%$ & $61,7 \%$ & $11,7 \%$ & $26,6 \%$ & $100,0 \%$ \\
\hline \multirow{2}{*}{ Y-Kuşağı } & $\mathrm{N}$ & 44 & 1 & 15 & 60 \\
\cline { 2 - 7 } & $\%$ & $73,3 \%$ & $1,7 \%$ & $25,0 \%$ & $100,0 \%$ \\
\hline
\end{tabular}

Markaların lüzumsuz olduğu görüşü \%46,9'la en çok Bebek Patlaması Kuşağında belirtilmiştir. Y kuşağı ise \%34,4 ile Bebek Patlaması kuşağına oldukça yakındır. X Kuşağına mensup bireyler ise \%18,8 ile markaların lüzumsuz olmadığını düşünmektedirler. Benzer yanıtlar, arkadaşlarımda gördüğüm bir markayı isterim sorusu için de görülmektedir. Ünlü markaların toplumun üst kesimlerini yansıttığını ise \%43,1 ile en çok Bebek Patlaması Kuşağı düşünmektedir. Bu noktada $X$ ve $Y$ kuşakları benzer tutumları belirtmişlerdir. Satın almadan önce diğerlerinin düşüncelerine önem veren Y Kuşağ $1 \% 73,3$ ile en yüksek yanıtı vermiştir.

Tablo 8. Kuşakların Yeme-İçme Tüketimi Alışkanlıkları

\begin{tabular}{|c|c|c|c|c|c|}
\hline \multicolumn{6}{|c|}{ Ayda Bir Kez Şık Bir Restoranda Yemek Beni Mutlu Eder } \\
\hline & & Katiliyorum & Kararsızım & Katılmiyorum & Total \\
\hline \multirow[t]{2}{*}{ Bebek-Patlaması Kuşağı } & $\mathrm{N}$ & 26 & 7 & 27 & 60 \\
\hline & $\%$ & $43,3 \%$ & $11,7 \%$ & $45,0 \%$ & $100,0 \%$ \\
\hline \multirow{2}{*}{ X-Kuşağ1 } & $\mathrm{N}$ & 39 & - & 21 & 60 \\
\hline & $\%$ & $65,5 \%$ & $0,0 \%$ & $35,5 \%$ & $100,0 \%$ \\
\hline \multirow{2}{*}{ Y-Kuşağ1 } & $\mathrm{N}$ & 31 & 24 & 5 & 60 \\
\hline & $\%$ & $51,7 \%$ & $8,3 \%$ & $40,0 \%$ & $100,0 \%$ \\
\hline \multicolumn{6}{|c|}{ Günlük Yeme Alışkanlklarmma Soya, Kinoa, Açai vb. Ürünleri Katmaya Çalışırım } \\
\hline & & Katıliyorum & Kararsızım & Katılmıyorum & Total \\
\hline \multirow[t]{2}{*}{ Bebek-Patlaması Kuşağı } & $\mathrm{N}$ & 15 & 10 & 35 & 60 \\
\hline & $\%$ & $25,0 \%$ & $16,7 \%$ & $58,3 \%$ & $100,0 \%$ \\
\hline \multirow{2}{*}{ X-Kuşağı } & $\mathrm{N}$ & 14 & 6 & 40 & 60 \\
\hline & $\%$ & $23,3 \%$ & $10,0 \%$ & $66,7 \%$ & $100,0 \%$ \\
\hline \multirow{2}{*}{ Y-Kuşağ1 } & $\mathrm{N}$ & 8 & 39 & 13 & 60 \\
\hline & $\%$ & $13,3 \%$ & $21,7 \%$ & $65,0 \%$ & $100,0 \%$ \\
\hline \multicolumn{6}{|c|}{ Haftada Bir Fast-Food Tüketirim } \\
\hline & & Katıliyorum & Kararsızım & Katılmiyorum & Total \\
\hline \multirow[t]{2}{*}{ Bebek-Patlaması Kuşağı } & $\mathrm{N}$ & 8 & 2 & 50 & 60 \\
\hline & $\%$ & $13,3 \%$ & $3,3 \%$ & $83,3 \%$ & $100,0 \%$ \\
\hline \multirow{2}{*}{ X-Kuşağı } & $\mathrm{N}$ & 14 & 4 & 42 & 60 \\
\hline & $\%$ & $23,3 \%$ & $6,7 \%$ & $70,0 \%$ & $100,0 \%$ \\
\hline \multirow{2}{*}{ Y-Kuşağı } & $\mathrm{N}$ & 46 & 6 & 8 & 60 \\
\hline & $\%$ & $76,7 \%$ & $10,0 \%$ & $13,3 \%$ & $100,0 \%$ \\
\hline
\end{tabular}

Kuşakların yeme-içme alışkanlıklarında "ayda bir kez şık bir restoranda yemek beni mutlu eder" önermesini \%65,5 ile en yüksek olumlayan X Kuşağı iken, Y Kuşağ $1 \% 51,7$ ile ikinci sıradadır. Son yıllarda tüm dünyada 
moda olan sağlıklı bir diyet izlemek konusunda ise Bebek Patlaması Kuşağı \%38,6 ile bu durumu en çok önemseyen kuşak olduğunu belirtmiştir. Bu önerme için de ilk önermeye karşıt olarak Y Kuşağı en az katılan kuşak olarak gözükmektedir.

Her üç kuşakta benzer oranlarda beslenme konusunda son gelişmeleri takip ettiklerini belirtmişlerdir. Bununla beraber her üç kuşakta beslenme alışkanlıklarının içine soya, kinoa, açai gibi yeni ürünleri koymak konusunda çekimser gözükmektedir. Bu konuda en çekimser kuşak ise \%21,6 oranında kararsızım diyen $\mathrm{Y}$ kuşağıdır. Haftada bir fast-food tüketirim önermesine en çok katılan kuşak \%67,6 ile Y Kuşağı olup, Bebek Patlaması Kuşağ $1 \% 11,8$ ile en az fastfood tüketen kuşaktır.

\section{Tartışma ve Sonuç}

Bilinçli ya da bilinçsiz bir edim olarak tüketim yaşamımızı sürdürebilmemiz için zorunludur. Ancak tüketimin nasıl yapıldığı bu olguyu farklılaştırmaktadır. Özellikle son iki yüz elli yıldır tüketim, zorunlu ya da lüks tüketim modernitenin ana konularından birisi olmuştur. $\mathrm{Bu}$ araştırmada tüketim kuşaklar bağlamında incelenmeye çalışılırken, tüketimi gerçekleştiren bireylerin birbirinden bağımsız olarak değerlendirilmezse hangi üst gruba veya gruplara dâhil olabileceği sorusu sorulmuştur. Araştırmanın sorusu olan kuşaklar tüketim gruplarını belirlemek için kullanılabilir mi? sorusuna yanıt aranmaya çalışılmıştır.

İlgili sorunun yanıtını bulmak için araştırmada, İstanbul'da ikamet eden 180 kişiye kuşaklar kategorileştirilerek hazırlanan anket uygulanmıştır.

Bebek Patlaması kuşağı için dikkat çekici bulgular arasında ilk olarak eğitim konusunda göstermiş oldukları atılım göze çarpmaktadır. AnnesiBabasının eğitim durumu açısından en geride olan kuşak olmalarına karşın kendilerini ve doğal olarak kendilerinden sonra gelen kuşakları ileri taşımayı başarmışlardır. Bu çalışmada Bebek Patlaması kuşağı diğer kuşaklar arasında "yiyecek-içecek ve zorunlu harcamalar", "giyim-kuşam" ve "başkalarına yardım" alanlarında en çok harcamayı gerçekleştiren kuşaklardır. Kredi kartı kullanım oranları diğer kuşaklara göre düşüktür ve geleneksel tüketim alışkanlıklarını devam ettirmektedirler. Bunun en kayda değer örneği de günlük gazete okumayı sürdürüyor olmalarıdır. 
X Kuşağı, Bebek Patlaması Kuşağından gelen birtakım özellikleri korumakla beraber yeni seçeneklere uyum sağlama ve tüketim konusunda Bebek Patlaması kuşağına göre daha cesur olabilme özelliklerini göstermektedir. Kredi kartı kullanma sayısı en yüksek olan X Kuşağı olup online platformlara üyelik, online gazete okuma alışkanlıkları, lüks tüketim alışkanlıkları gibi Bebek Patlaması kuşağında görece düşük olan yeni tüketim biçimlerine yönelmiş olmalarıdır. Bununla beraber eski alışkanlıklarından da tam olarak vazgeçememişlerdir ve TV'den alışveriş, online alışveriş konusunda Y Kuşağının bir hayli gerisinde kalmışlardır.

Araştırmanın bulgularına göre, Y Kuşağı tüketim konusunda dünyadaki genel yapı ile birleşen ve belki de gerçek anlamda tüketimin içine doğan bir kuşak olarak diğer kuşaklar arasında eğlenceye en çok pay ayıran kuşaktır. Kredi kartı sahipliği, online platformlarda vakit geçirmek gibi bulguları $\mathrm{X}$ Kuşağı ile aynı olmakla beraber bu platformdan alışveriş yapma konusunda $X$ Kuşağını bir hayli geride bırakmışlardır. Aynı şekilde günlük gazete okuma alışkanlığını da büyük bir ölçüde geride bırakarak aradaki köprüleri ortadan kaldıran bir kuşak olma görünümü sergilemektedirler. Benzer bir bulgu fast-food tüketiminde de görülmektedir. Y Kuşağ1 diğer kuşaklara nazaran haftada bir kez fast-food tüketirim sorusuna katıliyorum demiştir.

Sonuç olarak, üç kuşağın, yaşam pratikleri içerisinde tüketim rolünde, tüketimin önemi ve gündelik hayatlarındaki işlevinde, lüks tüketime bakışlarında, marka ve tüketim ilişkilerinde dünyaya paralel olarak değişim yaşandığı saptanmıştır.

Türkiye'nin kendi içerisinde yaşamış olduğu özgün durumlar olsa da kuşakların ortak hafızalarındaki tüketim gerçekliği, literatürle paralellikler göstermektedir. Araştırmada çıkan sonuçlar değerlendirildiğinde, bu üç kuşağın tüketim şekilleri arasındaki farkların en önemli nedeni teknolojik atılımın rolüdür. Bununla beraber kuşakların dönemin şartları, Türkiye'nin özel şartları, eğitim, çalışma gibi birçok kavrama bağlı olarak tüketimi değerlendirdikleri gözlemlenmiştir. Bu da çalışmanın yola çıkarken sorduğu soruların ve varsayımlarının çok büyük bir ölçüde doğrulandığını göstermektedir.

Tüketim ilişkilerinde yaşanan hızlı dönüşümler Türkiye'de de etkisini göstererek küreselleşmenin etkisiyle hızlı dışa açılma yeni bir tüketim sistemi ortaya çıkarmıştır. Tüketimin son dönemde ekonominin temelini oluşturması üretim-tüketim ilişkisinde dengeyi yok ederken bu ilişkinin kuşak- 
lar tarafından nasıl algılandığı da oldukça önemlidir. Türkiye'de yaşanan dönüşümün dünyadan oldukça farklı ve içsel dinamikleri bağlamında gerçekleştiğini söylemek imkânsız gözükmektedir. Bununla beraber, Türkiye'nin yaşamış olduğu üretim ilişkilerinde yaşanan dönüşümle dünyaya açlması ve neoliberal politikalar ile beraber dönüşen tüketim ilişkileri kuşaklarca, bir anlamda, "üretimi de tüketen bir sistem" olarak sürdürülmektedir. 


\title{
EXTENDED ABSTRACT
}

\section{A Socioeconomic Investigation On Changing Consumption Relations Between Generations}

\author{
Mehmet Cenker Tuncer-Nurgün Oktik \\ Maltepe Üniversitesi
}

In historical processes, there are different conceptualizations to understand and evaluate change and to describe the historical period to which they belong. The concept of generation is one of them. Comte asserts that generations are transmitters of the common knowledge of humanity. Through generations, history and all kinds of events that have happened in history are passed on to the next generation. Therefore, generations as transmitters of knowledge have a very important place in terms of continuity and renewal of society.

Generations are defined as groups that are the subject of a common narrative for each interpreter who defines the concept and positions it within a theoretical framework, are the experiencers and transmitters of a common narrative, and share a common period and space with the consciousness of a common history. Consequently, the period in which each of the generations lived affected the common consciousness of the generations and was shaped by the generations in the same way. One of the biggest factors in the formation of this common consciousness can be considered as economic structure.

While the phenomenon of consumption in sociology can be described as an action that has existed since the known human history, it started with the consumption of nature before the settled life of humanity and has shown changes depending on the processes of change of production relations. The concept of consumption, which is at the center of economic action, affects the generations living in each transformation period and is affected by the generations. In addition to the fact that studying generations is necessary for categorizing consumers in this study, it can also contribute to the assessment of generations of changes in consumption as a historical whole. 
The baby boomer period, which included the period 1946-1964, took its name from the rapidly growing population after the Second World War. Although Turkey did not enter the Second World War, as a country very close to the war, it remained in the position of keeping troops and implementing a war economy. Accordingly, it has brought with it difficult and troubled periods for the generations who lived in this period in Turkey. After the war, a process of rapid change began in the world in order to strengthen the economic structure and improve production. The baby boomer generation lived in Turkey under very similar conditions to the whole world.

The Baby Boomer Generation is similar around the world due to the external conditions, the famine economy and the self-sufficiency processes that develop due to the consumption being limited to the domestic market.

Generation X, which covers the periods 1965-1979, has grown with the "import-substitution" industrialization policy, which is a new period in Turkey. In addition to these developments in Turkey, after the Second World War, there was a shortage of workers in European countries that showed rapid acceleration in production.

During this period, migrations of workers from Turkey to Europe began. Along with the migrations of workers, Turkey has made a complete acquaintance with the European market, and consumption relations have changed rapidly accordingly. From the economic recovery that began in the 1960s and continued until the end of the 1970s, Turkey experienced a great change, especially in terms of consumption, and almost managed to sit in a parallel line with the world.

This phase, which includes the years 1980-1999, led to the expansion of the market and the "consumption-centered" that emerged in the world, causing Turkey to abandon the methods that it followed in the economy, such as 'statism' and 'protectionism', which enabled Turkey to articulate to the global economy. The 1980s can be considered as the years when both the economy and the balance of production-consumption relations changed.

After the 1980s, neoliberal policies became dominant throughout the world, and the policies of opening to the world have created an unbalanced distribution in the relations of production and consumption. Wide class of consumers has emerged with the shift of production to cheap labor markets and the Far East in production-consumption relations. 
In accordance with the purpose of the research to examine the change of consumption relations through generations, a survey was applied to 180 people living in Istanbul.

Among the remarkable findings for the baby boomer generation, their breakthrough in education stands out. Although they are the generation behind in terms of their mother and father's educational status, they have managed to move themselves and the generations that naturally came after them forward. In this study, the Baby Boomer generation is the generation that spend the most on "food and beverage and compulsory expenses", "clothing" and "helping others" among other generations.

Generation X, while maintaining several characteristics from the Baby Boom Generation, shows the ability to adapt to new options and be bolder in consumption than the Baby Boom generation. Generation $X$, which has the highest number of credit card uses, is that they have turned to new forms of consumption that are relatively low in the baby boomer generation, such as membership in online platforms, online newspaper reading habits, luxury consumption habits.

According to the findings of the study, Generation $\mathrm{Y}$ is the generation that shares the most share of entertainment among other generations as a generation that combines with the general structure of consumption in the world and is perhaps born into consumption in a real sense. Credit card ownership, such as spending time on online platforms, is the same as Generation $X$, but they have far left Generation $X$ behind when it comes to shopping on this platform.

As a result, it has been determined that three generations have experienced changes in the role of consumption in life practices, the importance of consumption and its function in their daily lives, their view of luxury consumption, brand, and consumption relations in parallel with the world.

\section{Kaynakça / References}

Aydemir, M. (2006). Yetinen toplumdan tüketen topluma; Türkiye'de Modern tüketim kültürünün tarihsel ve toplumsal gelişim seyri. Selçuk Üniversitesi Fen Edebiyat Fakültesi Dergisi, 16, 201-214

Başfırınc, Ç. (2011). Modern Türk tüketim kültürüne yönelik bir araştrma. Milli Folklor, 9, 115-129.

Boratav, K., (2005), Türkiye İktisat Tarihi 1908-2002, Ankara: İmge Yayınlan 
Çorum, A. A. (2012). Y Kuşağına yönelik insan kaynakları uygulamaları ve bir şirket örneği. (Yayımlanmamış yüksek lisans tezi). Bahçeşehir Üniversitesi/Sosyal Bilimler Enstitüsü, İstanbul.

Edgell, S., Hetherington, K., veWarde, A. (1996).Consumptio nmatters: the productionand experience of consumption.

Eğilmez, M., (2018), Değişim Sürecinde Türkiye, İstanbul: Remzi Kitabevi

Erkenekli, M., Uzun, Z., ve Gümüs, Ö. D. (2012). Sosyoekonomik statü ve sosyal değerler ilişkisine yönelik bir inceleme. Journal of DefenseSciences/Savunma Bilmleri Dergisi, 11(2).

Howe, N. (2009). The fourthturning. Crown/Archetype.

Karasar, N. (2005). Bilimsel araştırma yöntemleri. Ankara: Nobel Yayınları.

Keyder, Ç. (2001). Türkiye'de devlet ve sinuflar. İstanbul: İetişim Yayınları.

Pamuk, S.. (2018). Türkiyénin 200 ylllkk iktisadi tarihi. İstanbul: İş Bankası Yayınları

Mannheim, K. (2013). Essayssociology knowledge (Vol. 5). Routledge

Neuman, W. L. (2009). Toplumsalaraştırmayöntemleri: nitelvenicelyaklaşımlar: 1. cilt. Ankara: Yayınodası.

Sombart, W. (2008). Burjuva: Modern ekonomidönemineaitinsanmnahlakiveentelektüeltarihinekatkı. (çev. OğuzAdanır). Ankara: DoğuBatıYayınları.

Şalap, K. O. (2016). Çalışma yaşamında kuşaklar: Kuşakların iş ve özel yaşam dengesine ilişkin yaklaşımları. (Yayımlanmış Yüksek Lisans Tezi). İstanbul Üniversitesi, Sosyal Bilimler Enstitüsü, İstanbul.

Taş, H. Y., Demirdöğmez, M., ve Küçükoğlu, M. (2017). Geleceğimiz olan Z kuşağının çalışma hayatına muhtemel etkileri. OPUS Uluslararası Toplum Araştırmaları Dergisi, 7(13), 1031-1048.

Yerasimos, S. (1966). Azgelişmişlik sürecinde Türkiye. İstanbul:RemziKitabevi.

\section{Kaynakça Bilgisi / Citation Information}

Tuncer, C. M. ve Oktik, N.(2021). Kuşaklararası tüketim ilişkilerine sosyoekonomik bir bakıs. OPUS-Uluslararası Toplum Araştırmaları Dergisi, 17(37), 4352-4375. DOI: 10.26466/opus.765680 